Revista Eletrônica de Direito Processual - REDP.

Rio de Janeiro. Ano 16. Volume 23. Número 1. Janeiro a Abril de 2022 Periódico Quadrimestral da Pós-Graduação Stricto Sensu em Direito Processual da UERJ

Patrono: José Carlos Barbosa Moreira (in mem.). ISSN 1982-7636. pp. 1228-1254 www.redp.uerj.br

\title{
EM BUSCA DE UMA SISTEMATIZAÇÃO DO REGIME DE DESPESAS PROCESSUAIS DO PODER PÚBLICO ${ }^{1}$
}

\section{IN SEARCH OF A SYSTEMATIZATION OF THE PROCEDURAL EXPENSES REGIME INVOLVING LEGAL ENTITIES OF PUBLIC LAW}

\section{LA BÚSQUEDA DE SISTEMATIZACIÓN DEL RÉGIMEN DE COSTAS PROCESALES DE LAS PERSONAS DE DERECHO PÚBLICO}

Ravi Peixoto

Doutor em Direito Processual pela UERJ. Mestre em Direito pela UFPE. Procurador do Município do Recife. Advogado. Membro da ANNEP, do CEAPRO, da ABDPRO e do IBDP. Recife/PE. E-mail: ravipeixoto@gmail.com

RESUMO: O artigo se propõe, com base na legislação e jurisprudência, a estudar o regime das despesas processuais aplicáveis ao Poder Público. O desafio é o de sistematizar esse regime que é extremamente dependente da legislação extravagante federal e das legislações locais, no entanto, afigura-se possível uma sistematização geral da eventual isenção de algumas despesas, bem como do diferimento e necessidade do adiantamento de outras.

PALAVRAS-ChAVE: Despesas processuais; custas. Fazenda Pública; isenção.

\begin{abstract}
The paper aims to study the procedural expenses regime involving legal entities of public law based on Brazilian law and in decisions rendered by national courts. The main challenge is to arrange and organize this regime, which is simultaneously subordinated to federal law and local legislation. However, it is possible to propose a general systematization, especially related to the eventual expense release and its deferral and advance.
\end{abstract}

\footnotetext{
${ }^{1}$ Artigo recebido em 17/09/2021 e aprovado em 26/10/2021.
} 
KEYWORDS: Procedural expenses; costs; legal entities of public law; release.

RESUMEN: El articulo tiene el propósito de estudiar, con base en la legislación y decisiones judiciales, el régimen de costas procesales de las personas de derecho público. La sistematización es compleja, pues son muchos los regímenes en las diversas legislaciones, sean de derecho federal o local. Pero, mismo con esas dificultades, es posible proponer un régimen que enfrente la dispensa de algunas costas, la autorización para el pago tardío y mismo la necesidad de adelantamiento de algunos tipos de costas.

PALABRAS-CLAVE: Costas procesales; costas; personas de derecho público; dispensa de pago.

\section{INTRODUÇÃO}

O tema das despesas processuais, embora muito relevante para a atuação dos operadores do direito, não é, em geral, objeto de preocupação da doutrina. Não é difícil de imaginar as razões, afinal, não envolve teorização sobre os grandes institutos do direito processual.

Um tema ainda mais esquecido é o das despesas processuais do poder público, que possuem um regime ainda mais particular e que acaba sendo alterado a depender do procedimento e a depender da pessoa jurídica em questão. Temas como dispensa do pagamento, adiantamento ou não de despesas, constitucionalidade ou não das previsões legais, natureza jurídica do ente são comuns na jurisprudência, mas não na doutrina.

O objetivo desse texto é simples: organizar e refletir o regime das despesas processuais em relação ao poder público. Há muitas leis (federais e estaduais), julgados, sejam do STJ, STF e tribunais locais, mas a questão ainda é bastante desorganizada, não havendo uma sistematização desse regime jurídico.

O texto, inicialmente, fará uma análise dos tipos de despesas processuais existentes no direito processual. A partir dessa diferenciação, será possível analisar como cada uma dessas espécies se comporta em relação à Fazenda Pública e como as diversas previsões 
Revista Eletrônica de Direito Processual - REDP.

Rio de Janeiro. Ano 16. Volume 23. Número 1. Janeiro a Abril de 2022

Periódico Quadrimestral da Pós-Graduação Stricto Sensu em Direito Processual da UERJ

Patrono: José Carlos Barbosa Moreira (in mem.). ISSN 1982-7636. pp. 1228-1254

www.redp.uerj.br

na legislação extravagante atuam sobre esse tema. Nesse sentido, passa a ser possível analisar o regime geral previsto no CPC, as diversas previsões de isenção legal, bem como as suas exceções.

\section{ESPÉCIES DE DESPESAS PROCESSUAIS}

As despesas processuais consistem em desembolsos pecuniários realizados pelos participantes da relação processual, tendo como causa direta e imediata a atividade processual. ${ }^{2}$ Atualmente, os honorários não são considerados como despesas processuais, o que também ocorre com as multas impostas por desvios de comportamento das partes. ${ }^{3}$ Também não o são as despesas extraprocessuais, como gastos para preparação do processo ou por causa dele, como viagens e alimentação das partes ou defensores, não sendo sequer objeto de interesse para o processo civil. ${ }^{4}$

O CPC afirma no art. 84 que "As despesas abrangem as custas dos atos do processo, a indenização de viagem, a remuneração do assistente técnico e a diária de testemunha", texto normativo de baixa densidade. Isso porque ele não indica o regime dessas despesas, muito menos é taxativo. Tem-se aqui apenas exemplos ${ }^{5}$ de despesas processuais, mas que devem ser diferenciadas de acordo com seu regime e titularidade.

Há várias formas de diferenciar as diversas despesas processuais. Renato Beneduzi as diferencia entre judiciais, que abrange as custas e a remuneração dos auxiliares da justiça e as extrajudiciais, destinadas a agentes não estatais, como honorários, indenização de viagem, diária de testemunha etc. ${ }^{6}$ Como apontado, os honorários não são tratados como despesa pelo CPC. Além disso, a diferenciação tem pouca utilidade para efeitos de diferenciação do seu regime processual, pelo qual não será adotada. Prefere-se adotar uma

\footnotetext{
${ }^{2}$ ASSIS, Araken de. Processo civil brasileiro. São Paulo: RT, 2015, v. II, t. I, p. 335.

3 ASSIS, Araken de. Processo civil brasileiro... cit., p. 335-336; CAMARGO, Luiz Henrique Volpe. Comentários ao art. 84. In: DIDIER JR., Fredie; WAMBIER, Teresa Arruda Alvim; TALAMINI, Eduardo; DANTAS, Bruno (coord.). Breves comentários ao novo código de processo civil. São Paulo: RT, 2015, p. 300. ${ }^{4}$ DINAMARCO, Candido Rangel. Instituições de direito processual civil. $7^{\mathrm{a}}$ ed. São Paulo: Malheiros, 2017, t. II, p. 743.

${ }^{5}$ Apontando seu caráter exemplificativo: BENEDUZI, Renato. Comentários ao código de processo civil. São Paulo: RT, 2018, t, II, versão eletrônica, comentários ao art. 84, item 1; CAMARGO, Luiz Henrique Volpe. Comentários ao art. 84... cit., p. 299.

${ }^{6}$ BENEDUZI, Renato. Comentários ao código de processo civil... cit., comentários ao art. 84, item 1.
} 
Revista Eletrônica de Direito Processual - REDP.

Rio de Janeiro. Ano 16. Volume 23. Número 1. Janeiro a Abril de 2022

Periódico Quadrimestral da Pós-Graduação Stricto Sensu em Direito Processual da UERJ

Patrono: José Carlos Barbosa Moreira (in mem.). ISSN 1982-7636. pp. 1228-1254

www.redp.uerj.br

que foque mais na diferenciação do seu regime, especial, no que é pertinente ao Poder Público

Em uma primeira aproximação, tem-se as custas judiciais, que são diferenciadas entre as custas em sentido estrito e as taxas judiciárias. Ambas são taxas, ou seja, são receitas tributárias. ${ }^{7} \mathrm{O}$ desafio é a sua diferenciação, que advém não de sua natureza, mas do tipo de serviço financiado por cada uma delas.

As custas judiciais são devidas pelo processamento do feito, englobando o financiamento do serviço que é prestado pelos distribuidores, escrivães, oficiais de justiça, contadores etc. Por sua vez, a taxa judiciária é devida em razão da atuação dos serviços dos magistrados e membros do Ministério Público. ${ }^{8}$

A outra diferenciação é em relação aos emolumentos, que objetivam remunerar serviços prestados pelos serventuários de cartórios não oficializados, que são remunerados pelo valor dos serviços cobrados e não pelo erário público. Seriam dispêndios exigidos para as atividades cartorárias extrajudiciais. Eles também possuem natureza de taxa, de acordo com a jurisprudência do $\mathrm{STF}^{9}$.

Por fim, tem-se as despesas em sentido estrito, que se referem à remuneração de terceiros que atuam na consecução da atividade jurisdicional, mas não são por ele remunerados, como honorários do perito, despesas postais com citações e intimações, transporte do oficial de justiça, diária de testemunhas que não seja funcionária pública e que não trabalhe sob o regime da Consolidação das Leis do Trabalho etc. Embora as citações e intimações sejam preparadas por servidores públicos, os gastos com os correios visam remunerar terceiros, não tendo, assim, natureza tributária. ${ }^{10} \mathrm{~A}$ mesma lógica se aplica aos gastos com o transporte do oficial de justiça para o cumprimento dos atos.

\footnotetext{
${ }^{7}$ STF, Tribunal Pleno, Rp 1.077, Rel. Min. Moreira Alves, j. 28/03/1984, DJ 28/09/1984; STF, Tribunal Pleno, ADI 3.694, Rel. Min. Sepúlveda Pertence, j. 20/09/2006, DJ 06/11/2006; STF, Tribunal Pleno,ADI 2.653, Rel. Min. Carlos Velloso, j. 08/10/2003, DJ 31/10/2003; STJ, 1 ${ }^{\mathrm{a}}$ T., REsp 1.097.307/RS, Rel. Min. Francisco Falcão, j. 10/03/2009, DJe 18/03/2009.

8 Diagnósticos das custas processuais praticadas nos tribunais. Brasília, 2019, disponível em https://www.cnj.jus.br/wp-content/uploads/2019/11/relatorio_custas_processuais2019.pdf, acesso em 13/08/2021, p. 11. Também assim na jurisprudência do STF: STF, Tribunal Pleno, Rp 1.077, Rel. Min. Moreira Alves, j. 28/03/1984, DJ 28/09/1984, p. 65 do acórdão.

${ }^{9}$ STF, Tribunal Pleno, ADI 3.694, Rel. Min. Sepúlveda Pertence, j. 20/09/2006, DJ 06/11/2006; STF, Tribunal Pleno, ADI 1.145, Rel. Min. Carlos Velloso, j. 03/10/2002, DJ 08/11/2002.

${ }^{10}$ Cf. voto do ministro Menezes Direito em: STF, Tribunal Pleno, ADI 3.154, Rel. Min. Dias Toffoli, Relator(a) p/ Acórdão: Ricardo Lewandowski, j. 13/10/2020, DJe 05/02/2021.
} 
Revista Eletrônica de Direito Processual - REDP.

Rio de Janeiro. Ano 16. Volume 23. Número 1. Janeiro a Abril de 2022 Periódico Quadrimestral da Pós-Graduação Stricto Sensu em Direito Processual da UERJ

Patrono: José Carlos Barbosa Moreira (in mem.). ISSN 1982-7636. pp. 1228-1254 www.redp.uerj.br

Outros exemplos podem ser mencionados, como os honorários do intérprete, do depositário, do conciliador e do mediador. Tem-se ainda o porte de remessa e retorno dos autos ou do instrumento, que não pode ser confundido com as custas recursais. Para o STF, tem-se aqui uma despesa destinada a remunerar o serviço postal, não detendo natureza de taxa. ${ }^{11}$

A diferenciação pode variar a depender do regime jurídico do órgão do Poder Judiciário em questão. Isso porque, nada impede que o conciliador e o mediador sejam servidores concursados do Poder Judiciário, que serão remunerados pelo poder público, custeados pelas partes através das custas e não por honorários. Da mesma forma, a legislação de custas pode incluir, em seu pagamento, as despesas com os correios, com o transporte do oficial de justiça ou mesmo optar pela sua separação.

Essa diferenciação é importante para entes públicos e privados, mas especialmente para o poder público, como se verá. Isso porque as pessoas físicas e pessoas jurídicas de direito privado devem arcar com todos esses gastos, mas as pessoas jurídicas de direito público, por vezes, são dispensadas do pagamento das custas, mas não das despesas em sentido estrito.

\section{AS CUSTAS E O PODER PÚBLICO}

A primeira questão a ser analisada é o regime das custas. Em relação aos particulares, o seu regime jurídico está previsto no art. 82 do CPC: salvo gratuidade da justiça, "incumbe às partes prover as despesas dos atos que realizarem ou requererem no processo, antecipando-lhes o pagamento, desde o início até a sentença final ou, na execução, até a plena satisfação do direito reconhecido no título". Ao fim, "A sentença condenará o vencido a pagar ao vencedor as despesas que antecipou” (art. 82, §2, CPC).

No caso do Poder Público, o funcionamento é diferente. Isso porque, de acordo com o art. 91 do CPC, “As despesas dos atos processuais praticados a requerimento da Fazenda Pública, do Ministério Público ou da Defensoria Pública serão pagas ao final pelo vencido". Significa, então, que os entes públicos são dispensados do adiantamento das despesas, que deve ser realizado apenas ao final do processo, pelo vencido.

${ }^{11}$ STF, $2^{\mathrm{a}}$ T., RE 571.978-AgR, Rel. Min. Cezar Peluso, DJE 29.8.2008. 
Revista Eletrônica de Direito Processual - REDP.

Rio de Janeiro. Ano 16. Volume 23. Número 1. Janeiro a Abril de 2022

Periódico Quadrimestral da Pós-Graduação Stricto Sensu em Direito Processual da UERJ

Patrono: José Carlos Barbosa Moreira (in mem.). ISSN 1982-7636. pp. 1228-1254

www.redp.uerj.br

Para Dinamarco, essa dispensa de adiantamento das custas teria por fundamento o fato de que os entes públicos sempre são solventes e o de que o Estado, na defesa do patrimônio público, sempre atuaria de forma criteriosa. O mesmo autor responde que os estados são solventes, mas a maioria não cumpre o pagamento dos precatórios e também de que, na prática, o Estado seria o maior responsável pelo acúmulo de litígios, propondo demandas e resistindo de forma abusiva. ${ }^{12}$ A afirmação do autor, em relação aos precatórios é válida, embora não se conheça uma pesquisa empírica que confirme haver uma generalidade nos atrasos de precatórios. Além disso, ao afirmar que o Estado seria um litigante irresponsável, parecem faltar dados que comprovem que o Poder Público seria um litigante que resistiria de forma mais abusiva do que os particulares em situações semelhantes.

De certa forma, o art. 91, caput, excepciona o art. 82, $\S 2^{\circ}$, do CPC, pois, caso o Poder Público seja vencedor, a parte sucumbente não irá ressarcir a outra parte das despesas adiantadas. Na verdade, ela irá recolher aos cofres públicos aquilo que não foi adiantado pelo poder público. Caso o sucumbente seja o Poder Público, este deverá recolher aos cofres públicos os valores não adiantados e também ressarcir a parte vitoriosa dos valores por ela adiantados.

Um exemplo de confirmação de que aos entes públicos compete o pagamento das custas pode ser visualizado na súmula 178 do STJ, segundo a qual "O INSS não goza de isenção do pagamento de custas e emolumentos, nas ações acidentárias e de benefícios, propostas na Justiça Estadual". ${ }^{13}$ Há também julgados do STJ que ressaltam não ser a Fazenda Pública dispensada do pagamento de emolumentos, havendo apenas seu diferimento para o final do processo. ${ }^{14}$

Ainda do ponto de vista geral, o art. 91 do CPC aponta para que todas as despesas dos atos praticados a requerimento da Fazenda Pública devem ser pagas apenas ao final pelo vencido. Ocorre que existem despesas que são arcadas por terceiros, não vinculados ao Poder Judiciário, que sequer são remunerados por taxas.

\footnotetext{
12 DINAMARCO, Candido Rangel. Instituições de direito processual civil... cit., p. 757.

${ }^{13}$ Esse entendimento sumulado do STJ será objeto de análise crítica mais a frente.

${ }^{14}$ STJ, $1^{\text {a }}$ T., AgInt no AREsp 381.536/RS, Rel. Min. Napoleão Nunes Maia Filho, j. 28/03/2017, DJe 05/04/2017.
} 
Revista Eletrônica de Direito Processual - REDP.

Rio de Janeiro. Ano 16. Volume 23. Número 1. Janeiro a Abril de 2022

Periódico Quadrimestral da Pós-Graduação Stricto Sensu em Direito Processual da UERJ

Patrono: José Carlos Barbosa Moreira (in mem.). ISSN 1982-7636. pp. 1228-1254

www.redp.uerj.br

Essa é, por exemplo, a situação do perito. Mesmo antes do CPC de 2015, essa posição já prevalecia por meio da súmula 232 do STJ, segundo a qual “A Fazenda Pública, quando parte no processo, fica sujeita à exigência do depósito prévio dos honorários do perito".

No CPC de 2015, a legislação optou por sinalizar três diversas possibilidades em relação às perícias requeridas pela Fazenda Pública. A primeira delas é a sua realização por entidade pública (art. 91, $\left.\S 1^{\circ}\right) .{ }^{15}$ A segunda será, no caso de existir previsão orçamentária, ocorrer o adiantamento dos valores se o ente público requerer a produção da prova (art. $\left.91, \S 2^{\circ}\right)$.

A última hipótese ocorre no caso de inexistir previsão orçamentária. Nesta situação, não haverá adiantamento imediato dos honorários do perito, mas esses devem ser pagos no exercício seguinte ou ao final, pelo vencido, caso o processo se encerre antes do fim do exercício seguinte (art. $91, \S 2^{\circ}$ ). Frise-se que, nessa situação, o perito pode ter de esperar até quase dois anos para receber seus honorários. Basta imaginar perícia realizada em janeiro de 2021 em relação a ente público sem previsão orçamentária, que teria até o fim de 2022 para realizar esse pagamento.

A exigência do adiantamento dos valores também deve incidir para as demais despesas em sentido estrito. ${ }^{16}$ Não parece haver fundamento legal, por exemplo, para que as testemunhas sejam obrigadas a arcar com os gastos para a realização do seu depoimento, tendo de ficar à espera do final do processo para serem ressarcidas. Como veremos mais a frente, esse parece ser o fundamento do STF e do STJ para limitar as hipóteses de incidência das isenções legais aplicadas ao Poder Público na legislação extravagante.

\subsection{O caso do preparo recursal}

\footnotetext{
${ }^{15}$ Enfrentando o eventual problema da ausência de parcialidade do servidor público na realização da perícia: MARQUES, Leonardo Albuquerque; FREIRE, Alexandre. Comentários ao art. 91. In: CUNHA, Leonardo Carneiro da; STRECK, Lenio Luiz; NUNES, Dierle (orgs.). FREIRE, Alexandre (coord. exec.). $2^{a}$ ed. São Paulo: Saraiva, 2017, p. 166.

${ }^{16}$ No mesmo sentido: CUNHA, Leonardo Carneiro da. A Fazenda Pública em juízo. 17 ed. Rio de Janeiro: Forense, 2020, p. 115; SILVA NETO, Francisco Antônio de Barros e. A improbidade processual da Administração Pública e sua responsabilidade objetiva pelo dano processual. Rio de Janeiro: Lumen Juris, 2010, p. 205.
} 
Revista Eletrônica de Direito Processual - REDP.

Rio de Janeiro. Ano 16. Volume 23. Número 1. Janeiro a Abril de 2022

Periódico Quadrimestral da Pós-Graduação Stricto Sensu em Direito Processual da UERJ

Patrono: José Carlos Barbosa Moreira (in mem.). ISSN 1982-7636. pp. 1228-1254

www.redp.uerj.br

Há uma previsão que precisa de uma análise um pouco mais aprofundada, relacionada ao preparo recursal. Isso porque, de acordo com o art. $1.007, \S 1^{\circ}$, do CPC, "São dispensados de preparo, inclusive porte de remessa e de retorno, os recursos interpostos pelo Ministério Público, pela União, pelo Distrito Federal, pelos Estados, pelos Municípios, e respectivas autarquias, e pelos que gozam de isenção legal”. Pela dicção legal, há, em tese, dispensa da própria realização do preparo, inclusive porte de remessa e retorno e não apenas a imposição de que tal valor seja recolhido ao final do processo, pelo vencido.

Uma primeira aproximação seria a realização de uma interpretação conforme a constituição. Isso porque, se a interpretação dada fosse de simples isenção, haveria concessão de isenção heterônoma, que é vedada pelo art. 151, II, da CF. Afinal, essa previsão iria alterar o regime de custas dos Estados, em relação à justiça estadual, isentando os entes públicos, dentre outros, do pagamento de custas. Tal previsão apenas pode incidir em relação à justiça federal, que, como veremos, possui norma específica acerca da dispensa de custas.

Assim, a previsão da dispensa do preparo seria interpretada conforme a constituição, no sentido de que apenas dispensa os poderes públicos do adiantamento do preparo e não do seu pagamento. Caso ele seja vencido ao final, deverá recolher essas custas.

Essa parece ser a interpretação do STJ, quando da análise de necessidade de realização do prévio preparo pelo INSS na justiça estadual. Ao analisar o tema, a interpretação foi a de que o INSS não é isento de custas quanto na atuação na justiça estadual, mas teria o direito de não realizar o prévio preparo. Isso não significaria que estaria dispensado desse gasto processual, mas apenas que só deverá fazê-lo ao final, caso vencido. ${ }^{17}$

Inclusive, essa é a interpretação a ser dada à súmula 483 do STJ, segundo a qual "O INSS não está obrigado a efetuar depósito prévio do preparo por gozar das prerrogativas e privilégios da Fazenda Pública". Esse tema chegou a ser rediscutido no STJ, por meio do tema repetitivo 1.001, com reafirmação da jurisprudência e fixação da tese de que "A teor

${ }^{17}$ STJ, $6{ }^{\text {a }}$ T., AgRg no REsp 1.253.956/CE, Rel. Min. Maria Thereza De Assis Moura, j. 14/02/2012, DJe 27/02/2012. Igualmente: STJ, Corte Especial, REsp 1.101.727/PR, Rel. Min. Hamilton Carvalhido, j. 02/08/2010, DJe 23/08/2010. 
Revista Eletrônica de Direito Processual - REDP.

Rio de Janeiro. Ano 16. Volume 23. Número 1. Janeiro a Abril de 2022

Periódico Quadrimestral da Pós-Graduação Stricto Sensu em Direito Processual da UERJ

Patrono: José Carlos Barbosa Moreira (in mem.). ISSN 1982-7636. pp. 1228-1254

www.redp.uerj.br

dos arts. 27 e $511, \S 1^{\circ}$, do revogado CPC/73 (arts. 91 e 1.007, $\S 1^{\circ}$, do vigente $\mathrm{CPC} / 15$ ), o Instituto Nacional do Seguro Social - INSS, nos recursos de competência dos Tribunais de Justiça, está dispensado do prévio pagamento do porte de remessa e de retorno, enquanto parcela integrante do preparo, devendo recolher o respectivo valor somente ao final da demanda, acaso vencido". ${ }^{18}$

Ocorre que se exige certo esforço interpretativo que poderia ser resolvido por simples alteração redacional. $\mathrm{O}$ art. $1.007, \S 1^{\circ}$, do $\mathrm{CPC} / 2015$ repete a redação do art. $511, \S 1^{\circ}$ do CPC/1973. Uma boa alteração da redação poderia ser inspirada no art. 1.428 do CPC de Pernambuco, quando, ainda em 1925, afirmava que "Independem de preparo prévio que será pago ao final, os recursos interpostos ex-officio ou pelos representantes do Ministério Público e da Fazenda". Poderia haver, no art. 1.007 do CPC, um parágrafo específico para os entes que não possuem isenção, mas apenas uma dispensa do adiantamento preparo nos seguintes termos: "São dispensados de preparo prévio, inclusive porte de remessa e de retorno, os recursos interpostos pelo Ministério Público, pela União, pelo Distrito Federal, pelos Estados, pelos Municípios, e respectivas autarquias, os quais serão pagos ao final, pelo vencido".

Essa, no entanto, não parece ser a posição do STF. A discussão surgiu no RE 594.116, em que o objetivo era analisar a exigência do pagamento do porte de remessa e retorno por parte do INSS na justiça estadual. Aparentemente, a discussão acabou sendo resolvida por meio da afirmação de que "Aplica-se o $§ 1^{\circ}$ do art. 511 do Código de Processo Civil para dispensa de porte de remessa e retorno ao exonerar o seu respectivo recolhimento por parte do INSS". ${ }^{19}$ Assim, embora tenha surgido, durante as discussões, o tema da constitucionalidade do texto normativo, acabou, ao menos implicitamente, sendo ele considerado constitucional.

Em certo momento dos debates, o Ministro Luiz Fux destaca que "Em todos os casos em que o Código estabelece esta prerrogativa, a de que a Fazenda Pública não paga isso ou não paga aquilo, o Estado fica desfalcado, mas é por força de lei”. Além disso, do ponto de vista constitucional, "a Constituição estabelece que a lei pode disciplinar matéria processual. Preparo de recurso é requisito extrínseco de admissibilidade, e é matéria

${ }^{18}$ STJ, Corte Especial, REsp 1.761.119/SP, Rel. Min. Sérgio Kukina, j. 07/08/2019, DJe 14/08/2019.

${ }^{19}$ STF, Tribunal Pleno, RE 594.116, Rel. Min. Edson Fachin, j. 03/12/2015, DJe 05/04/2016. 
Revista Eletrônica de Direito Processual - REDP.

Rio de Janeiro. Ano 16. Volume 23. Número 1. Janeiro a Abril de 2022

Periódico Quadrimestral da Pós-Graduação Stricto Sensu em Direito Processual da UERJ

Patrono: José Carlos Barbosa Moreira (in mem.). ISSN 1982-7636. pp. 1228-1254

www.redp.uerj.br

processual". ${ }^{20}$ A partir dessa argumentação, conclui que seria possível a lei processual estabelecer dispensa de preparo do Poder Público, apesar de eventualmente onerar as finanças dos estados, que foi a ressalva levantada pelo Ministro Gilmar Mendes.

Como apontado anteriormente, o STF distingue as custas do porte de remessa e retorno, estando ambos incluídos no preparo. No entanto, por conta da dicção do art. 511, $\S 1^{\circ}$, do CPC/1973, reproduzido pelo art. $1.007, \S 1^{\circ}$, do $\mathrm{CPC} / 2015$, que expressamente dispensam o Poder Público do preparo, o aplicaram no caso concreto para resolver o caso. Por consequência, tendo por base a posição do STF, o Poder Público está efetivamente dispensado do pagamento do preparo em qualquer hipótese. ${ }^{21}$

A doutrina, em geral, ao comentar o tema, apenas aponta ser possível à legislação processual dispensar o preparo por requisitos objetivos ou subjetivos. O critério objetivo leva em conta a natureza do recurso ou do processo, a exemplo do agravo interno e dos embargos de declaração. O critério subjetivo leva em consideração o sujeito envolvido, a exemplo da Fazenda Pública. Em ambos os casos, não se cogita de deserção. ${ }^{22}$ Araken de Assis, por exemplo, ao se referir a essa dispensa de preparo, utiliza-se do termo isenção e não de dilatação do prazo para realização do preparo, se vencido o ente público. ${ }^{23}$ Não se verifica qualquer consideração acerca de inconstitucionalidade da dispensa do pagamento de tais valores, embora previstos em lei federal de forma genérica.

\footnotetext{
${ }^{20}$ A posição do Ministro Luiz Fux é declaradamente inspirada em obra do professor José Frederico Marques, que tinha posição semelhante. Em comentários à Emenda Constitucional n. 7, de 13 de abril de 1977, que passou a prever que caberia à União fixar normas gerais sobre custas, afirmou "Uma vez que a União legisla sobre Direito Processual, nada mais lógico que possa estabelecer normas gerais sobre as despesas processuais. É que, embora objeto de leis tributárias dos Estados, essas despesas têm intensa repercussão no processo. Donde poder a União fixar normas gerais a respeito do modo e forma de serem pagas as custas, e inclusive do próprio quantum a ser exigido dos litigantes (...) Além disso, os reflexos das custas e emolumentos na própria relação processual justificam plenamente a competência agora outorgada à União". (MARQUES, José Frederico. A reforma do poder judiciário. São Paulo: Saraiva, 1979, p. 149)

${ }^{21}$ Como visto, o STJ não dispensa o pagamento ao final do preparo pelo INSS. Ocorre que há julgado no qual aplicado o entendimento do STF, no sentido da simples dispensa do preparo: STJ, $2^{\mathrm{a}}$ T., REsp 1.723.271/SP, Rel. Min. Herman Benjamin, j. 03/04/2018, DJe 25/05/2018. Importa destacar que, pelo que se percebe das decisões do STJ, a interpretação da decisão do STF no RE 594.116 nem sequer abrangeu a dispensa de custas. Isso se percebe no inteiro teor das discussões no tema repetitivo 1.001, no qual mencionada a ementa do STF, mas sem qualquer discussão sobre o que fora lá discutido sobre dispensa de custas por parte do INSS. Cf: STJ, Corte Especial, REsp 1.761.119/SP, Rel. Min. Sérgio Kukina, j. 07/08/2019, DJe 14/08/2019.

22 BARBOSA MOREIRA, José Carlos. Comentários ao código de processo civil. 14 ed. Rio de Janeiro: Forense, 2008, v. V, p. 394-395. De forma semelhante, sem qualquer ressalva: KOZIKOSKI, Sandro Marcelo. Sistema recursal CPC/2015. Salvador: Juspodivm, 2015, p. 141.

${ }^{23}$ ASSIS, Araken de. Manual dos recursos. $9^{\mathrm{a}}$ ed. São Paulo: RT, 2017, p. 265.
} 
Revista Eletrônica de Direito Processual - REDP.

Rio de Janeiro. Ano 16. Volume 23. Número 1. Janeiro a Abril de 2022 Periódico Quadrimestral da Pós-Graduação Stricto Sensu em Direito Processual da UERJ

Patrono: José Carlos Barbosa Moreira (in mem.). ISSN 1982-7636. pp. 1228-1254 www.redp.uerj.br

Para Nelson Nery Junior, o tema do preparo tem natureza processual, sendo de competência exclusiva da União (art. 22, $i, \mathrm{CF}$ ). Assim, a ela caberia legislar sobre a "exigência, oportunidade de pagamento e efeitos do não pagamento" e aos Estados apenas estabelecer o valor das custas recursais. Complementa afirmando que como esse valor decorre dos serviços judiciários prestado pelo ente público, apenas eles "podem dizer quando ocorre a hipótese de incidência da taxa judiciária, isto é, o fato gerador do tributo". ${ }^{24}$

O que se percebe é a existência de uma divergência entre STJ e STF. Enquanto, para o STJ, não há isenção, mas apenas dispensa da realização do preparo prévio, o STF interpreta o art. 1.007, $\S 1^{\circ}$, do CPC, como isenção de pagamento do preparo. A doutrina, do que se pode compreender, não se aprofunda no tema constitucionalidade ou não dessa isenção de pagamento do preparo, mas, de forma implicitamente a acolhe.

Um interessante ponto de vista, embora não fique tão claro é o de Nelson Nery. Isso porque é preciso perceber que existem duas questões envolvidas: a exigência do preparo como requisito recursal (matéria processual) e a exigência do preparo em si (matéria tributária). Parecem a mesma coisa, mas são questões diferentes.

A exigência do preparo, como decorrência do serviço prestado pelo Poder Judiciário é uma questão de natureza tributária. Por conta disso, compete a cada ente legislar quando ele será exigido e seu valor, fato gerador, forma de cobrança etc. Por outro lado, não compete a esses entes regular as consequências processuais do seu não pagamento. Essa consequência, ou sua inserção como requisito de admissibilidade recursal compete à União, por ser matéria de direito processual.

Isso significa, por exemplo, que quando a União legisla sobre direito processual e dispensa o Poder Público do preparo como requisito processual, não há dispensa desse tributo. Isso seria inconstitucional, por se configurar como isenção heterônoma. O que ocorre é que, optando o Estado por exigir pagamento de custas pelo Poder Público, deverá cobrar esses valores de outra forma, não podendo haver reconhecimento da deserção. Partindo da previsão do CPC, tal valor apenas poderia ser cobrado processualmente ao final, nos termos do art. 91, do vencido.

Note-se que esse raciocínio pode e deve ser extrapolado para outras situações de dispensa de custas pela União, em lei federal. Um exemplo singelo é no caso dos

\footnotetext{
${ }^{24}$ NERY JR., Nelson. Teoria geral dos recursos. 6 a ed. São Paulo: RT, 2004, p. 426.
} 
Revista Eletrônica de Direito Processual - REDP.

Rio de Janeiro. Ano 16. Volume 23. Número 1. Janeiro a Abril de 2022

Periódico Quadrimestral da Pós-Graduação Stricto Sensu em Direito Processual da UERJ

Patrono: José Carlos Barbosa Moreira (in mem.). ISSN 1982-7636. pp. 1228-1254

www.redp.uerj.br

embargos de declaração (art. 1.023, CPC), no qual há dispensa do preparo. Esse texto normativo não obriga os estados, que podem optar por exigir o pagamento de custas em tal situação, do contrário, haveria isenção heterônoma. O que os Estados não podem fazer é exigir que a parte realize o preparo para a interposição do recurso, ou seja, ele não pode ser julgado deserto. A consequência é a de que o valor poderá ser cobrado da parte e, em não sendo pago, poderá ser inscrito em dívida ativa e cobrado pelo Estado, mas não pode ter como consequência a deserção do recurso.

\section{DISPENSA DAS CUSTAS}

\subsection{A confusão e a atuação do Estado perante a sua própria justiça estadual}

Como visto, em regra, o Poder Público não está dispensado das custas, mas apenas do seu adiantamento. Ocorre que, em algumas situações, é possível vislumbrar a possibilidade de alguma espécie de não incidência do tributo, por meio do instituto da confusão.

Essa possibilidade poderia ocorrer quando há atuação do próprio ente estatal, em relação à justiça por ele mantida. Por exemplo, o Estado de Pernambuco atuando no TJPE. Nessas hipóteses, não seria cabível o pagamento das custas, porque haveria confusão. Afinal, o ente público estaria pagando as custas para si mesmo.

Essa é a posição da maioria dos tribunais, a exemplo do TJES, segundo o qual há confusão na condenação do Estado ao pagamento de custas processuais. Apenas lhe caberia restituir ao autor as custas que este houver eventualmente des embolsado no início do processo. ${ }^{25}$ A mesma posição já foi adotada pelo TJSP, ${ }^{26} \mathrm{TJTO}^{27}$ e TJRJ ${ }^{28}$ Não foi possível encontrar outros julgados nesse sentido de outros tribunais estaduais até porque,

25 TJES, $2^{\text {a }}$ C. Cível, APL: 00037382820008080024, Rel. Des. Álvaro Manoel Rosindo Bourguignon, j. 31/08/2010, DJ 15/10/2010. No mesmo sentido: TJES, $3^{\text {a }}$ C. Cível, Classe: Embargos de Declaração Ap Civel, 24070222559, Rel. Ronaldo Gonçalves De Sousa, j. 02/03/2010, DJ: 16/03/2010; TJES, 3ª C. Cível, Embargos de Declaração Ap Civel, 50070048363, Rel. Benicio Ferrari, j. 19/01/2010, DJ 01/02/2010.

${ }^{26}$ TJSP, $6^{\text {a }}$ C. de Direito Público 10013886520178260505 SP 1001388-65.2017.8.26.0505, Rel. Des. Leme de Campos, j. 09/08/2018, DJ 09/08/2018.

${ }^{27}$ TJTO, Remessa Necessária Cível: 00160354720198270000, Rel. Des. Celia Regina Regis, j. 17/07/2019.

${ }^{28}$ TJRJ, $3^{\text {a C}}$. Cível, APL: 00187775020088190001, Rel. Des. Renata Machado Cotta, j. 06/02/2019. 
Revista Eletrônica de Direito Processual - REDP.

Rio de Janeiro. Ano 16. Volume 23. Número 1. Janeiro a Abril de 2022

Periódico Quadrimestral da Pós-Graduação Stricto Sensu em Direito Processual da UERJ

Patrono: José Carlos Barbosa Moreira (in mem.). ISSN 1982-7636. pp. 1228-1254

www.redp.uerj.br

como será demonstrado, na grande maioria deles, há dispensa legal ao pagamento das custas pela Fazenda Pública.

No entanto, para o TJPR, não há confusão. Em diversos julgados, afirma-se que o Estado, apesar de instituir a taxa, pode ser sujeito passivo da obrigação tributária. Isso porque a "Constituição Federal, em seu art. 150, inc. IV, alínea a, enuncia expressamente as hipóteses de imunidade tributária aos entes políticos. E dele não consta a imunidade ou isenção à Fazenda que institui determinado tributo". ${ }^{29}$ Especificamente quanto à alegação de confusão, afirma-se que "as figuras de sujeito ativo e sujeito passivo não se confundem na mesma pessoa, uma vez que as custas se constituem receitas destinadas ao próprio Poder Judiciário". 30

O tema chegou a ser objeto de incidente de uniformização de jurisprudência, ${ }^{31}$ do qual se editou a súmula 72: "É cabível a condenação da Fazenda Pública estadual ao pagamento das custas processuais nos casos em que a serventia for estatizada, não havendo que se falar em confusão patrimonial".

Aponta destacar que o tema não foi analisado pelo STF porque, de acordo com a Corte, para a decisão sobre o tema, haveria necessidade de análise da legislação infraconstitucional e local, incidindo a súmula $280 .{ }^{32}$ Por outro lado, o STJ também não tem admitido a análise do tema, porque seria matéria decidida apenas por fundamento exclusivamente constitucional. ${ }^{33}$

$\mathrm{Na}$ doutrina, Francisco Antônio de Barros e Silva Neto tem posicionamento semelhante. Para o autor, uma vez que o art. $98, \S 2^{\circ}$, da Constituição da República impõe a destinação das custas para o custeio dos "serviços afetos às atividades específicas da

${ }^{29}$ TJPR, $1^{\text {a }}$ Câmara Cível, APL: 15155314 PR 1515531-4 (Acórdão), Relator: Juiz Fernando César Zeni, j. 19/04/2016, DJ: 1791 03/05/2016; TJPR, 1ª Câmara Cível, EDC - 1165612-1/01 - Região Metropolitana de Londrina - Foro Central de Londrina - Rel.: Juiz Fernando César Zeni - Unânime - J. 23.09.2014; TJPR - $1^{\mathrm{a}}$ C. Cível - 0000098-07.1999.8.16.0193 - Colombo - Rel.: Desembargador Salvatore Antonio Astuti - J. 10.02.2020.

${ }^{30}$ TJPR - $1^{\text {a }}$ C. Cível - 0000098-07.1999.8.16.0193 - Colombo - Rel.: Desembargador Salvatore Antonio Astuti, j. 10.02.2020.

${ }^{31}$ TJPR, Seção Cível, IUJ - 1329914-8/01 - Região Metropolitana de Londrina -Foro Central de Londrina Rel.: Silvio Dias - Unânime, j. 20.11.2015.

${ }^{32}$ STF, ARE 1.334.577 PR, Rel. Min. Luiz Fux, j. 06/07/2021, DJ 08/07/2021.

33 STJ, REsp 1.927.050 PR 2021/0072969-6, Rel. Min. Regina Helena Costa, DJ 28/04/2021, decisão monocrática. 
Revista Eletrônica de Direito Processual - REDP.

Rio de Janeiro. Ano 16. Volume 23. Número 1. Janeiro a Abril de 2022

Periódico Quadrimestral da Pós-Graduação Stricto Sensu em Direito Processual da UERJ

Patrono: José Carlos Barbosa Moreira (in mem.). ISSN 1982-7636. pp. 1228-1254

www.redp.uerj.br

justiça", não há confusão. Afinal, os valores pagos a título de custas não voltam para o próprio ente público e devem ser destinados a atividade específica. ${ }^{34}$

Situação semelhante e que pode servir de parâmetro envolve a defensoria pública e o pagamento de honorários quando esta litiga com seu ente de origem. ${ }^{35}$

Ainda está em vigor a súmula n. 421, do STJ, editada em 2010, segundo a qual "Os honorários advocatícios não são devidos à Defensoria Pública quando ela atua contra a pessoa jurídica de direito público à qual pertença".

Ocorre que, desde então, foi concedida maior autonomia financeira e orçamentária às defensorias. Inicialmente, tem-se a EC 45/2004, que inseriu no art. 134, §2 ${ }^{\circ}$, da CF, a autonomia funcional e administrativa. Em 2009, a LC 132/2009 passou a prever que os honorários da defensoria pública seriam destinados "a fundos geridos pela Defensoria Pública e destinados, exclusivamente, ao aparelhamento da Defensoria Pública e à capacitação profissional de seus membros e servidores". Isso ainda seria reforçado pela EC 80/2014. Tendo por base essas alterações, o STF, que havia reconhecido em 2008 ausência de repercussão geral sobre o tema, ${ }^{36}$ entendeu, em ação rescisória, pelo cabimento de honorários da União em relação à DPU, rechaçando a existência de confusão. ${ }^{37}$ Posteriormente, foi reconhecida repercussão geral sobre o tema. ${ }^{38}$

Note-se que o raciocínio é análogo ao que pode ser feito para as custas judiciais. A vinculação da receita a um determinado órgão impede que haja a confusão entre credor e devedor, por mais que, rigorosamente, credor e devedor façam parte de uma mesma pessoa jurídica. Portanto, a lógica é a de que a confusão é excluída pela previsão de vinculação das receitas a determinados fundos. No caso, as custas serão dirigidas

\footnotetext{
${ }^{34}$ SILVA NETO, Francisco Antônio de Barros e. A improbidade processual da Administração Pública e sua responsabilidade objetiva pelo dano processual... cit., p. 206.

${ }^{35}$ Com mais vagar sobre o tema, cf.: ROCHA, Jorge Bheron; OLIVEIRA, Alfredo Emanuel Farias de; NEVES, Otávio Vilela Miranda. A defensoria pública e os honorários de sucumbência: breves anotações sobre a súmula 421 do Superior Tribunal de Justiça. In: ROCHA, Jorge Bheron; OLIVEIRA, Alfredo Emanuel Farias de; PITTARI, Mariella; MAIA, Maurilio Casas. Teoria geral da defensoria pública. Belo Horizonte: D’Plácido, 2020.

${ }^{36}$ STF, Tribunal Pleno, RE 592.730 RG, Rel. Min. Menezes Direito, Tribunal Pleno, DJe 21/11/2008.

${ }^{37}$ STF, Tribunal Pleno, AR 1.937 AgR, Rel. Gilmar Mendes, j. 30/06/2017, DJe 09/08/2017.

${ }^{38}$ STF, Tribunal Pleno, RE 1.140.005 RG, Rel. Min. Roberto Barroso, j. 03/08/2018, DJe 10/08/2018. Vale frisar que o STJ ainda se mostra avesso à revisão da súmula n. 421, pois, em recente julgado, afirmou que "o verbete da Súmula 421/STJ já foi editado no contexto da autonomia funcional e administrativa da Defensoria Pública, não estando presentes os requisitos para o overruling” (STJ, 1ª Seção, AgInt na Rcl 37.830/MS, Rel. Min. Og Fernandes, j. 10/06/2020, DJe 14/08/2020).
} 
Revista Eletrônica de Direito Processual - REDP.

Rio de Janeiro. Ano 16. Volume 23. Número 1. Janeiro a Abril de 2022

Periódico Quadrimestral da Pós-Graduação Stricto Sensu em Direito Processual da UERJ

Patrono: José Carlos Barbosa Moreira (in mem.). ISSN 1982-7636. pp. 1228-1254

www.redp.uerj.br

"exclusivamente ao custeio dos serviços afetos às atividades específicas da Justiça", diferenciando-a do orçamento do próprio ente público, não havendo vedação a que haja cobrança de custa por parte do Poder Judiciário em relação à pessoa jurídica de direito público da qual faz parte.

\subsection{As dispensas legais de pagamento de custas do Poder Público}

Para além da discussão sobre a confusão, em diversos momentos, são editadas leis que dispensam o Poder Público do pagamento de custas. Talvez o mais famoso exemplo seja o art. 39 da Lei 6.830/1980: “A Fazenda Pública não está sujeita ao pagamento de custas e emolumentos. A prática dos atos judiciais de seu interesse independerá de preparo ou de prévio depósito". ${ }^{39}$ No entanto, a dispensa atua tão apenas para a execução fiscal, independentemente de onde esteja tramitando.

Mais uma vez, poderia, no momento, surgir a discussão sobre a inconstitucionalidade da isenção heterônoma, no sentido de que, tendo sido a legislação editada pela União, não poderia isentar o pagamento das custas na justiça estadual. ${ }^{40}$ Ocorre que, até o momento, não se conhece posição do STF sobre o tema e o STJ vem aplicando a legislação sem suscitar qualquer espécie de inconstitucionalidade, ${ }^{41}$ mesmo que a execução fiscal tramite na justiça estadual. ${ }^{42}$

Há julgado do STF que poderia atuar no sentido da validade da norma, pois, ao menos a título de obiter dictum, ao analisar alterações nas taxas judiciárias, o Ministro Moreira Alves ${ }^{43}$ utilizou-se do raciocínio do doutrinador Frederico Marques para admitir

\footnotetext{
${ }^{39}$ De acordo com a exposição de motivos da Lei de Execuções Fiscais, a previsão teve por objetivo impedir a paralisação dos processos, pois existiriam diversas decisões determinando o prévio adiantamento das custas processuais, apesar da previsão do art. 27 do CPC/73, equivalente ao atual art. 91 do CPC. Ou seja, a opção foi a de simplesmente isentar o Poder Público das custas, tendo em vista a existência de decisões que, aparentemente, negavam vigência a texto normativo que garantia o diferimento do pagamento das despesas de atos realizados a pedido da Fazenda Pública.

${ }^{40}$ Nesse sentido: MOLITERNO, Marcella Parpinelli. Garantias e privilégios da Fazenda Públic na execução fiscal. In: FERREIRA FILHO, Marcílio da Silva; LIMA, Rodrigo Medeiros de (coords.). Execução fiscal: teoria, prática e atuação fazendária. $2^{a}$ ed. Belo Horizonte: Fórum 2017, p. 107-108. Essa é a posição no TJPR: TJPR, 2a C. Cível, APL: 00102357520018160129 PR 0010235-75.2001.8.16.0129 (Acórdão), Rel. Des. Antônio Renato Strapasson, j. 10/03/2020, DJ 10/03/2020; TJPR. AC no 1.684.476-7. Rel. Des. Silvio Vericundo Fernandes Dias. j. 18/07/2017.

${ }^{41}$ STJ, $2^{\text {a }}$ T., AgInt no AREsp 1.000.602/RS, Rel. Min. Og Fernandes, j. 18/05/2020, DJe 22/05/2020.

${ }^{42}$ STJ,REsp 1.264.637/PR, Rel. Min. Mauro Campbell Marques, DJe 25/08/2011.

${ }^{43}$ STF, Tribunal Pleno, Rp 1.077, Rel. Min. Moreira Alves, j. 28/03/1984, DJ 28/09/1984, p. 59 do acórdão.
} 
Revista Eletrônica de Direito Processual - REDP.

Rio de Janeiro. Ano 16. Volume 23. Número 1. Janeiro a Abril de 2022

Periódico Quadrimestral da Pós-Graduação Stricto Sensu em Direito Processual da UERJ

Patrono: José Carlos Barbosa Moreira (in mem.). ISSN 1982-7636. pp. 1228-1254

www.redp.uerj.br

que, como à União compete a fixação de normas processuais, apesar de reconhecer se tratar de tributos devidos aos estados, também poderia editar normas sobre o modo e a forma de cobrança das custas mesmo na justiça estadual, por interferirem diretamente na relação processual, inclusive ao quantum a ser exigido. Note-se que esse mesmo raciocínio foi utilizado recentemente pelo Ministro Luiz Fux no 594.116 para admitir a aplicação da dispensa de realização do preparo mesmo na justiça estadual para entes público federais.

Como apontado anteriormente, essa posição não está correta. A legislação federal não pode dispensar tributos de natureza estadual, pois seria isenção heterônoma, nos termos do art. 151, II, da CF.

Outro exemplo ocorre com a dispensa das custas de toda a Fazenda Pública no âmbito da justiça federal, nos termos do art. $4^{\circ}$, I, da Lei 9.289: “Art. $4^{\circ}$ São isentos de pagamento de custas: I - a União, os Estados, os Municípios, os Territórios Federais, o Distrito Federal e as respectivas autarquias e fundações". Importa frisar que essa isenção não alcança as entidades fiscalizadoras do exercício profissional (art. $4^{\circ}$, parágrafo único, da Lei 9.289/1996).

Esses entes, de acordo com o art. 58 da Lei 9.469/1998, seriam pessoas jurídicas de direito privado. No entanto, o STF declarou inconstitucional esse texto normativo, já que tais entidades exercem poder de polícia e, por essa razão, devem possuir natureza autárquica. ${ }^{44}$ São, então, autarquias especiais. Por conta disso, em regra, eles são considerados como integrantes da Fazenda Pública, tendo, por exemplo, o benefício da intimação pessoal constante do art. 25 da Lei de Execução Fiscal. ${ }^{45}$

Ocorre que a previsão normativa que os excluía da dispensa do pagamento de custas fazia todo o sentido sob a égide de sua natureza jurídica original, mas não quando são caracterizadas como autarquias especiais. De toda forma, como há previsão legal específica, essas autarquias acabam sendo detentoras de um regime jurídico específico em relação às custas.

Frise-se que, para o STJ, o parágrafo único do art. $4^{\circ}$ seria uma espécie de norma especial subjetiva dirigida aos conselhos de fiscalização profissional e que seria aplicável

\footnotetext{
${ }^{44}$ STF, Tribunal Pleno, ADIn 1717/DF, Rel. Min. Sydney Sanches, DJ 28.03.2003.

${ }^{45}$ STJ, $1^{\text {a }}$ Seção, REsp 1.330.473/SP, Rel. Min. Arnaldo Esteves Lima, j. 12/06/2013, DJe 02/08/2013.
} 
Revista Eletrônica de Direito Processual - REDP.

Rio de Janeiro. Ano 16. Volume 23. Número 1. Janeiro a Abril de 2022

Periódico Quadrimestral da Pós-Graduação Stricto Sensu em Direito Processual da UERJ

Patrono: José Carlos Barbosa Moreira (in mem.). ISSN 1982-7636. pp. 1228-1254

www.redp.uerj.br

não apenas à justiça federal, mas a todos os órgãos do Poder Judiciário. Nesse sentido, entende que esses entes, apesar de serem autarquias, não são beneficiados pela dispensa de realização do preparo que consta do art. $1.007, \S 1^{\circ}$, do CPC. $^{46}$

Esse posicionamento está sujeito a críticas. Isso porque o que consta da Lei 9.289/1996 não é uma previsão legal específica dos conselhos de fiscalização profissional, mas voltada apenas para a justiça federal. Ampliar a incidência do texto normativo também para a justiça estadual é ignorar o fato de que se trata de autarquia especial e, caso não haja norma específica, deve ter todas as prerrogativas da Fazenda Pública.

Há um outro exemplo que poderia trazer alguns problemas do ponto de vista de constitucionalidade. De acordo com o art. 24-A da Lei 9.028/1996, “A União, suas autarquias e fundações, são isentas de custas e emolumentos e demais taxas judiciárias, bem como de depósito prévio e multa em ação rescisória, em quaisquer foros e instâncias". Em resumo, mesmo na justiça estadual, a União e suas autarquias estariam isentas de custas.

Há texto normativo anterior, embora voltado apenas para o INSS, no qual, de acordo com o art. $8^{\circ}, \S 1^{\circ}$, da Lei 8.620/1993: "O INSS é isento do pagamento de custas, traslados, preparos, certidões, registros, averbações e quaisquer outros emolumentos, nas causas em que seja interessado nas condições de autor, réu, assistente ou opoente, inclusive nas ações de natureza trabalhista, acidentária e de benefícios".

A doutrina já apontou a inconstitucionalidade do art. 24-A, pois haveria previsão de tributo estadual por lei federal, o que configuraria isenção heterônoma. ${ }^{47} \mathrm{Na}$ jurisprudência, há poucas manifestações sobre o tema, mas, quando aparece, o texto normativo vem sendo simplesmente aplicado. ${ }^{48}$ No STJ, apenas é possível encontrar acórdão abordando a Lei 8.620/1993, no qual prevaleceu a posição de que "não pode a lei

${ }^{46}$ STJ, $1^{a}$ Seção, REsp 1.338.247/RS, Rel. Min. Herman Benjamin, j. 10/10/2012, DJe 19/12/2012, tema repetitivo n. 625. No mesmo sentido: STJ, $2^{\mathrm{a}}$ T., AgInt no AREsp 1.447.018/SP, Rel. Min. Og Fernandes, j. 01/12/2020, DJe 10/12/2020; STJ, $1^{\text {a }}$ T., AgInt no AREsp 1.236.401/RJ, Rel. Min. Benedito Gonçalves, j. 18/11/2019, DJe 20/11/2019.

${ }^{47}$ CUNHA, Leonardo Carneiro da; DIDIER JR., Fredie. Curso de direito processual civil. 15 ed. Salvador: Juspodivm, 2018, v. 3, p. 159.

${ }^{48}$ TJES, $1^{a}$ C. Cível, APL: 00052121320108080047, Rel. Des. Fabio Clem De Oliveira, j. 11/11/2014, DJ $18 / 11 / 2014$. 
Revista Eletrônica de Direito Processual - REDP.

Rio de Janeiro. Ano 16. Volume 23. Número 1. Janeiro a Abril de 2022

Periódico Quadrimestral da Pós-Graduação Stricto Sensu em Direito Processual da UERJ

Patrono: José Carlos Barbosa Moreira (in mem.). ISSN 1982-7636. pp. 1228-1254

www.redp.uerj.br

federal isentar o INSS de custas estaduais, em respeito a autonomia estadual e princípio federativo, inscritos na própria constituição federal (arts. 24, IV e 25)" ${ }^{49}$

Uma questão não devidamente analisada pelo STJ consiste na compatibilidade entre o art. 24-A da Lei 9.028/1996 e a súmula n. 178. De acordo com a mencionada súmula, "O INSS não goza de isenção do pagamento de custas e emolumentos, nas ações acidentárias e de benefícios, propostas na Justiça Estadual”.

Essa súmula foi editada em 1996, mas o art. 24-A apenas foi inserido na Lei 9.025/1996 em 2001. Ocorre que de forma indistinta, o STJ continua aplicando a súmula, não se encontrando qualquer menção à (in)constitucionalidade do art. 28-A da Lei 9.028/1996. ${ }^{50} \mathrm{O}$ que se pode presumir é o de que o STJ acaba ignorando o art. 24-A, da Lei 9.028/1996, porque já havia reconhecido a inconstitucionalidade do art. $8^{\circ}, \S 1^{\circ}$, da Lei 8.620/1993. Apenas há de se frisar que se presume a constitucionalidade dos textos normativos e que em nenhum caso o STJ instaurou incidente de decretação de inconstitucionalidade ou houve qualquer decisão da corte especial. Assim, as decisões do STJ que admitem a cobrança de custas do INSS quando litiga na justiça estadual violam o art. 97 da Constituição e a súmula vinculante n. 10 do STF.

Para além dessas legislações que dispensam o pagamento de custas, ainda sobram três grandes possibilidades de cobrança, para além da discussão sobre a confusão: i) dos municípios, em qualquer justiça estadual; ii) dos estados e do Distrito Federal, quanto não estejam atuando no tribunal de justiça que seja integrante do ente estatal e iii) da União, na justiça estadual, o que só ocorre em situações extremamente excepcionais, vide a atração da competência para a justiça federal, caso se considere o art. 24-A da Lei 9.028/1996 inconstitucional. A confirmar essa terceira hipótese, afirma o art. $1^{\circ}, \S 1^{\circ}$, da Lei 9.289/1996, que "Rege-se pela legislação estadual respectiva a cobrança de custas nas causas ajuizadas perante a Justiça Estadual, no exercício da jurisdição federal”.

Há uma tendência dos estados em replicar a legislação da União, dispensando a Fazenda Pública federal, estadual e municipal do pagamento das custas, com raras exceções. Isso pode ser visualizado a partir da seguinte tabela:

49 STJ, $3^{\text {a }}$ Seção, EREsp 66.653/SC, Rel. Min José Dantas, Rel. p/ Acórdão Min. William Patterson, j. 24/04/1996, DJ 24/06/1996.

${ }^{50}$ STJ, $2^{\text {a }}$ T., REsp 1.647.679/GO, Rel. Min. Herman Benjamin, j. 14/03/2017, DJe 20/04/2017; STJ, $2^{\text {a }}$ T., REsp 1.686.798/SE, Rel. Min. Francisco Falcão, j. 03/11/2020, DJe 20/11/2020. 
Revista Eletrônica de Direito Processual - REDP.

Rio de Janeiro. Ano 16. Volume 23. Número 1. Janeiro a Abril de 2022

Periódico Quadrimestral da Pós-Graduação Stricto Sensu em Direito Processual da UERJ

Patrono: José Carlos Barbosa Moreira (in mem.). ISSN 1982-7636. pp. 1228-1254 www.redp.uerj.br

\begin{tabular}{|c|c|c|}
\hline Estado & $\begin{array}{l}\text { Dispensa de } \\
\text { custas }\end{array}$ & Fundamento normativo \\
\hline Acre & Sim & $\begin{array}{l}\text { Art. } 2^{\circ} \text { São isentos do pagamento de taxas judiciárias e } \\
\text { emolumentos: I - a União, os Estados, os Municípios e } \\
\text { o Distrito Federal (Lei 1.422/2001) }\end{array}$ \\
\hline Alagoas & Não há previsão. & \\
\hline Amapá & Sim & $\begin{array}{l}\text { Art. 18. São isentos do pagamento de custas: VIII - a } \\
\text { União, os Estados, o Distrito Federal, os Municípios, e } \\
\text { suas respectivas autarquias, exceto quanto aos valores } \\
\text { devidos a peritos, arbitradores e intérpretes. (Lei } \\
1.436 / 2009 \text { ) }\end{array}$ \\
\hline Amazonas & Sim & $\begin{array}{l}\text { Art. 17, IX - São isentos do pagamento de custas } \\
\text { judiciais. IX - A União, os Estados, o Distrito Federal, } \\
\text { os Municípios, os Territórios Federais e as respectivas } \\
\text { autarquias e fundações públicas de direito público, } \\
\text { exceto quanto aos valores devidos a peritos, arbitradores } \\
\text { e intérpretes (Lei 4.408/2016) }\end{array}$ \\
\hline Bahia & Sim & $\begin{array}{l}\text { Art. } 10 \text { - São isentos do pagamento de taxas: IV - a } \\
\text { União, os Estados, o Distrito Federal e os Municípios. } \\
\text { (Lei } 12.373 / 2011 \text { ) }\end{array}$ \\
\hline Ceará & Sim & $\begin{array}{l}\text { Art. } 5^{\circ} \text { São isentos do pagamento de despesas } \\
\text { processuais: I - a União, os Estados, os Municípios, os } \\
\text { Territórios Federais, o Distrito Federal e as respectivas } \\
\text { autarquias e fundações; (Lei 16.132/2016) }\end{array}$ \\
\hline $\begin{array}{l}\text { Distrito } \\
\text { Federal }\end{array}$ & $\begin{array}{l}\text { Apenas o Distrito } \\
\text { Federal }\end{array}$ & $\begin{array}{l}\text { Art. 185. São isentos do recolhimento de custas } \\
\text { processuais: I - o Distrito Federal e suas autarquias e } \\
\text { fundações; (Provimento Geral Da Corregedoria, de } \\
\text { 13/10/2014) }\end{array}$ \\
\hline Espírito Santo & Apenas do Estado & $\begin{array}{l}\text { Art. 20. São dispensados do pagamento de custas } \\
\text { processuais: V - O Estado do Espírito Santo, suas } \\
\text { Autarquias, Fundações Públicas e Agências } \\
\text { Reguladoras; (Lei 9.974) }\end{array}$ \\
\hline Goiás & Não há previsão & \\
\hline Maranhão & Sim & $\begin{array}{l}\text { Art. 12. São isentos do pagamento de custas: I - a União, } \\
\text { os Estados, os Municípios, os Territórios e o Distrito } \\
\text { Federal, suas autarquias e as suas fundações que não } \\
\text { explorem atividade econômica; (Lei 9.109/2009) }\end{array}$ \\
\hline Mato Grosso & Sim & $\begin{array}{l}\text { Art. } 3^{\circ} \text { Além dos casos previstos em lei, são isentos do } \\
\text { pagamento de emolumentos, despesas e custas: I - a } \\
\text { União, o Estado e o Município, salvo quanto aos valores } \\
\text { despendidos pela parte vencedora da demanda (Lei } \\
7.603 / 2001 \text { ) }\end{array}$ \\
\hline $\begin{array}{l}\text { Mato Grosso } \\
\text { do Sul }\end{array}$ & & $\begin{array}{l}\text { Art. 24. São isentos do recolhimento da taxa judiciária: } \\
\text { I - a União, os Estados, os Municípios e respectivas } \\
\text { autarquias e fundações; (Lei 3.779/2009) }\end{array}$ \\
\hline Minas Gerais & Sim & $\begin{array}{l}\text { Art. 10.- São isentos do pagamento de custas: I - a } \\
\text { União, o Estado de Minas Gerais e seus Municípios e as } \\
\text { respectivas autarquias e fundações (Lei 14.939/2003) }\end{array}$ \\
\hline Pará & Sim & $\begin{array}{l}\text { Art. 40. São isentos do pagamento das custas } \\
\text { processuais: I- a União, os Estados, os Municípios, o }\end{array}$ \\
\hline
\end{tabular}


Revista Eletrônica de Direito Processual - REDP.

Rio de Janeiro. Ano 16. Volume 23. Número 1. Janeiro a Abril de 2022

Periódico Quadrimestral da Pós-Graduação Stricto Sensu em Direito Processual da UERJ

Patrono: José Carlos Barbosa Moreira (in mem.). ISSN 1982-7636. pp. 1228-1254

www.redp.uerj.br

\begin{tabular}{|c|c|c|}
\hline & & $\begin{array}{l}\text { Distrito Federal, suas autarquias e fundações públicas; } \\
\text { (Lei } 8.328 / 2015 \text { ) }\end{array}$ \\
\hline Paraíba & Sim & $\begin{array}{l}\text { Art. } 29 \text { - A Fazenda Pública vencida, não está sujeita } \\
\text { ao pagamento de custas, mais fica obrigada a ressarcir o } \\
\text { valor das despesas feitas pela parte vencedora (Lei } \\
5.672 / 1992 \text { ) }\end{array}$ \\
\hline Paraná & Não & $\begin{array}{l}\text { Art. 18. As custas a cargo da Fazendo Pública estadual } \\
\text { e municipal serão pagas mediante despacho da } \\
\text { autoridade competente, em requerimento, devidamente } \\
\text { instruído, firmado pelo escrivão do feito, por si e em } \\
\text { nome dos demais interessados, exceto as da } \\
\text { distribuição, que serão pagas no ato. (Lei 6.149/1970) }\end{array}$ \\
\hline Pernambuco & Não & \\
\hline Piauí & Sim & $\begin{array}{l}\text { Art. } 9^{\circ} \text { Respeitado o disposto no artigo anterior não } \\
\text { serão cobradas custas judiciais nas causas relativas aos } \\
\text { seguintes feitos, enquanto a lei de regência assim } \\
\text { determinar: V - nas ações em que forem autores ou } \\
\text { sucumbentes a União, Estados, Município e demais } \\
\text { pessoas jurídicas de direito público interno. (Lei } \\
6.920 / 2016 \text { ) }\end{array}$ \\
\hline Rio de Janeiro & Sim & $\begin{array}{l}\text { Art. } 115 \text { - Nos processos contenciosos em que sejam } \\
\text { autores a União, os Estados, os Municípios, o Distrito } \\
\text { Federal, as autarquias do Estado do Rio de Janeiro ou } \\
\text { pessoas no gozo do benefício da justiça gratuita, a taxa } \\
\text { será devida pela parte contrária, na execução, quando } \\
\text { condenada ou no caso de aquiescência ao pedido. } \\
\text { Parágrafo único - A aplicação da regra prevista no } \\
\text { "caput" deste artigo está condicionada quanto à União, } \\
\text { aos Estados e ao Distrito Federal, à concessão de igual } \\
\text { benefício ao Estado do Rio de Janeiro e suas autarquias } \\
\text { e, quanto aos Municípios, à concessão de isenção de } \\
\text { taxas e contribuições relacionadas ao patrimônio do } \\
\text { Estado do Rio de Janeiro e, de suas autarquias e } \\
\text { fundações públicas. (Decreto-Lei n. 05, de } 15 \text { de Março } \\
\text { de 1975, Código Tributário do Estado do Rio de } \\
\text { Janeiro) }\end{array}$ \\
\hline $\begin{array}{l}\text { Rio Grande do } \\
\text { Norte }\end{array}$ & Sim & $\begin{array}{l}\text { Art. } 1^{\circ} \text {. (...) } \S 1^{\circ} \text {. A União, o Estado do Rio Grande do } \\
\text { Norte, os Municípios desta Unidade da Federação, as } \\
\text { Autarquias Estaduais e as Fundações Públicas Estaduais } \\
\text { não estão sujeitos ao pagamento dos valores previstos } \\
\text { no caput, desde que se trate de atos de interesse } \\
\text { exclusivo destes Entes de direito público (Lei } \\
9.278 / 2009 \text { ) }\end{array}$ \\
\hline $\begin{array}{l}\text { Rio Grande do } \\
\text { Sul }\end{array}$ & Sim & $\begin{array}{l}\text { Art. 5. }{ }^{\circ} \text { São isentos do pagamento da taxa: } \\
\text { I - a União, os Estados, os Municípios, os Territórios } \\
\text { Federais, o Distrito Federal e as respectivas autarquias } \\
\text { e fundações (Lei 14.634/2014) }\end{array}$ \\
\hline Rondônia & Sim & $\begin{array}{l}\text { Art. } 5^{\circ} \text {. São isentos do pagamento de custas: I - a União, } \\
\text { os Estados, o Distrito Federal, os Municípios, e }\end{array}$ \\
\hline
\end{tabular}


Revista Eletrônica de Direito Processual - REDP.

Rio de Janeiro. Ano 16. Volume 23. Número 1. Janeiro a Abril de 2022

Periódico Quadrimestral da Pós-Graduação Stricto Sensu em Direito Processual da UERJ

Patrono: José Carlos Barbosa Moreira (in mem.). ISSN 1982-7636. pp. 1228-1254 www.redp.uerj.br

\begin{tabular}{|l|l|l|}
\hline & & $\begin{array}{l}\text { respectivas autarquias, bem como por aqueles que } \\
\text { gozam de isenção legal (Lei 3.896/2016 }\end{array}$ \\
\hline Roraima & Sim & $\begin{array}{l}\text { Art. } 8^{\circ} \text { São isentos do pagamento de custas judiciais: I- } \\
\text { a União, os Estados, os Municípios e o Distrito Federal; } \\
\text { (Lei 1.157/2016) }\end{array}$ \\
\hline Santa Catarina & Sim & $\begin{array}{l}\text { Art. 7 }{ }^{\circ} \text { São isentos do recolhimento da Taxa de Serviços } \\
\text { Judiciais: I - a União, os Estados, os Municípios, o } \\
\text { Distrito Federal e as respectivas autarquias e fundações } \\
\text { (Lei 17.654/2018) }\end{array}$ \\
\hline São Paulo & Sim & $\begin{array}{l}\text { Artigo } 6^{\circ} \text { - A União, o Estado, o Município e respectivas } \\
\text { autarquias e fundaçôes, assim como o Ministério } \\
\text { Público estão isentos da taxa judiciária. (Lei } \\
11.608 / 2003)\end{array}$ \\
\hline Sergipe & Não & $\begin{array}{l}\text { Art. } 1^{\circ}, \S 6^{\circ} \text { As despesas dos atos processuais praticados } \\
\text { a requerimento da Fazenda Pública, do Ministério } \\
\text { Público ou da Defensoria Pública devem ser pagas ao } \\
\text { final pelo vencido (Lei 8.345/2017) }\end{array}$ \\
\hline Tocantins & Não &
\end{tabular}

Dentre todos os estados da federação, não possuem uma dispensa geral apenas Alagoas, Distrito Federal, Goiás, Paraná, Pernambuco, Sergipe e Tocantins. Dentre eles, o único de que se tem notícia que vem cobrando custas até do Estado é o TJPR.

Mesmo aqueles que garantem a isenção, a previsão varia. A maioria, de fato, garante de forma indistinta a dispensa ao pagamento de custas. Mas, por exemplo, o Rio Grande do Norte apenas dispensa o Estado do Rio Grande do Norte, os Municípios desta Unidade da Federação e desde que se trate de atos de interesse exclusivo destes Entes de direito público. Assim, outros estados e municípios de outros estados não serão beneficiados pela dispensa de custas.

\subsection{Limites das isenções das custas}

Mesmo com diversas previsões de isenção, isso não significa que o Poder Público está dispensado de dispender diversos valores em decorrência da litigância, mesmo nesses casos. Isso porque, como veremos, uma regra geral é a de que as despesas em sentido estrito não estão abrangidas pela isenção das custas e emolumentos.

A principal fonte de precedentes sobre a temática é o art. 39 da LEF, por estar em vigor há certo tempo e ter vários julgados do STJ. Ele será a principal base para a 
Revista Eletrônica de Direito Processual - REDP.

Rio de Janeiro. Ano 16. Volume 23. Número 1. Janeiro a Abril de 2022

Periódico Quadrimestral da Pós-Graduação Stricto Sensu em Direito Processual da UERJ

Patrono: José Carlos Barbosa Moreira (in mem.). ISSN 1982-7636. pp. 1228-1254

www.redp.uerj.br

compreensão de que tipos de valores devem ser arcados pelo Poder Público, apesar da previsão de isenção tributária.

Antes de passar às situações nas quais a isenção legal não incide, cumpre esclarecer também as situações nas quais houve divergência jurisprudencial, prevalecendo a isenção legal.

No recurso especial 1.107.543, no qual decidido o tema repetitivo $202,{ }^{51}$ a discussão envolvia obrigatoriedade ou não de a Fazenda Pública, em sede de execução fiscal, proceder ao adiantamento dos valores relativos à expedição de ofício ao Cartório competente, para fornecimento de cópias dos atos constitutivos da executada. Em outros termos, envolvia o adiantamento ou não de emolumentos. É perceptível que houve certa confusão no acórdão originário, que dava entender que apenas haveria isenção do adiantamento e não do pagamento de tais valores.

A questão só foi esclarecida após a oposição de diversos embargos de declaração e confronto com as notas taquigráficas originais, ${ }^{52}$ no qual chegou-se à conclusão de que "O cartório extrajudicial deve expedir certidão sobre os atos constitutivos da empresa devedora executada requerida pela Fazenda Pública, cabendo-lhe, se vencida, reembolsar o valor das custas ao final”. Em suma, de que o ente público está isento de pagamento dos emolumentos, apenas cabendo-lhe ressarcir o que for despendido pela parte adversa. ${ }^{53}$

Importa recordar aqui que, dentre as despesas processuais, tem-se as despesas em sentido estrito, que não são tributos. São valores pagos a terceiros, não relacionado com a atividade jurisdicional e, por conta disso, não são abrangidos pelas legislações que dispensam a fazenda pública do "pagamento de custas e emolumentos", a exemplo do art. 39 da LEF. Um exemplo mencionado na doutrina é a despesa com transporte e remoção de bens penhorados. ${ }^{54}$

\footnotetext{
${ }^{51}$ STJ, $1^{\text {a }}$ Seção, REsp 1.107.543/SP, Rel. Min. Luiz Fux, j. 24/03/2010, DJe 26/04/2010.

${ }^{52}$ STJ, $1^{a}$ Seção, EDcl no REsp 1.107.543/SP, Rel. Min. Luiz Fux, j. 23/06/2010, DJe 01/07/2010; STJ, 1 $^{\text {a }}$ Seção, EDcl nos EDcl no REsp 1107543/SP, Rel. Min. Napoleão Nunes Maia Filho, j. 26/10/2011, DJe 18/11/2011; STJ, $1^{\text {a }}$ Seção, EDcl nos EDcl nos EDcl no REsp 1.107.543/SP, Rel. Min. Napoleão Nunes Maia Filho, j. 10/10/2012, DJe 26/10/2012; STJ, 1 ${ }^{a}$ Seção, EDcl nos EDcl nos EDcl nos EDcl no REsp 1.107.543/SP, Rel. Min. Napoleão Nunes Maia Filho, j. 13/09/2017, DJe 19/09/2017.

${ }^{53}$ Nesse sentido, também após embargos de declaração e tendo por base o precedente mencionado na nota n. 50: STJ, $1^{a}$ T., EDcl no AgRg no REsp 1.276.844/RS, Rel. Min. Napoleão Nunes Maia Filho, j. 15/12/2016, DJe 06/02/2017.

${ }^{54}$ THEODORO JÚNIOR, Humberto. Lei de execução fiscal. 13a ed. São Paulo: Saraiva, 2016, versão digital, item 232.
} 
Revista Eletrônica de Direito Processual - REDP.

Rio de Janeiro. Ano 16. Volume 23. Número 1. Janeiro a Abril de 2022

Periódico Quadrimestral da Pós-Graduação Stricto Sensu em Direito Processual da UERJ

Patrono: José Carlos Barbosa Moreira (in mem.). ISSN 1982-7636. pp. 1228-1254

www.redp.uerj.br

Passando às questões nas quais há posicionamento do STF e do STJ sobre a obrigação de adiantamento das despesas, tem-se os gastos de transporte do oficial de justiça.

O primeiro julgado a ser referenciado sobre o tema advém do STF, que analisou o tema no RE 108.845, de relatoria do Ministro Moreira Alves. Nesse julgado, restou consignado que o art. 39 da LEF não poderia abranger os gastos com atos exteriores ao processo, mas apenas os atos de responsabilidade da serventia. Fazer incidir o art. 39 da LEF seria impor que o oficial de justiça tivesse de esperar o fim do processo para, não receber, caso vencedora a Fazenda Pública, ou receber através do pagamento da parte vencida. Assim, como o art. 39 não abrange essa situação, não haveria lei que o obrigasse a realizar tal ato sem o adiantamento das despesas.

No STJ, o tema acabou consolidado da mesma forma, nos termos da súmula 190 do STJ: "Na execução fiscal, processada perante a justiça estadual, cumpre a fazenda pública antecipar o numerário destinado ao custeio das despesas com o transporte dos oficiais de justiça".

Buscando os fundamentos da súmula, o próprio STJ remete a um incidente de uniformização de jurisprudência de $1997 .{ }^{55}$ Nesse incidente, na verdade, não há uma análise aprofundada da questão, que é remetida a um julgado anterior, que seriam os embargos de divergência 22.649-SP ${ }^{56}$ e o recurso especial 22.618. ${ }^{57}$

No recurso especial 22.618, o ministro relator, Milton Pereira, ${ }^{58}$ apontou que é necessário diferenciar custas, emolumentos e despesas com diligências fora de cartório. A dispensa de pagamento de custas da Fazenda Pública não poderia impor que oficial de justiça ou perito seja obrigado a financiar suas atividades profissionais. Assim, “inexistindo obrigação legal, improcede impor-se prestação de serviço, na expectativa, $a d$ futurum, do pagamento". Assim, seja sob o prisma da legalidade ou do discernimento do bom senso, seria inadmissível impor ao oficial de justiça e ao perito arcar com as despesas decorrentes da execução de atos judiciais, ficando à espera de um pagamento no futuro.

\footnotetext{
${ }^{55}$ STJ, $1^{\text {a }}$ Seção, IUJur no RMS 1.352 SP, Rel. Min. Ari Pargendler, j. 26/02/1997, DJ 19/05/1997.

${ }^{56}$ STJ, $1^{\text {a }}$ Seção, EREsp 22.630/SP, Rel. Min. Garcia Vieira, j. 08/06/1993, DJ 06/09/1993.

${ }^{57}$ STJ, $1^{a}$ T., Resp 22.618/SP, Rel. Min. Garcia Vieira, Rel. p/acórdão Cesar Rocha, j. 25/10/1992, DJ 01/03/1993.

${ }^{58}$ STJ, $1^{\text {a }}$ Seção, EREsp 22.630/SP, Rel. Min. Garcia Vieira, j. 08/06/1993, DJ 06/09/1993.
} 
Revista Eletrônica de Direito Processual - REDP.

Rio de Janeiro. Ano 16. Volume 23. Número 1. Janeiro a Abril de 2022

Periódico Quadrimestral da Pós-Graduação Stricto Sensu em Direito Processual da UERJ

Patrono: José Carlos Barbosa Moreira (in mem.). ISSN 1982-7636. pp. 1228-1254

www.redp.uerj.br

Ocorre que acabou prevalecendo posição contrária, capitaneada pelo ministro César Rocha, tendo por base a súmula 154 do TFR, ${ }^{59}$ que inclui as despesas com oficial de justiça no conteúdo do art. 39 da LEF. Foi apenas nos embargos de divergência 22.469, de relatoria do ministro Milton Pereira que a posição do STJ foi consolidada no sentido da exigência do adiantamento desses valores.

Há de se frisar que a súmula aponta para a exigência desse adiantamento na justiça estadual, de onde se originaram os julgados. Ocorre que esse mesmo raciocínio deve ser aplicado para a justiça federal. Afinal, de acordo com o art. $4^{\circ}$, I, da Lei 9.289, a isenção é de custas. Assim, a ratio decidendi dos julgados que formam a súmula aplica-se igualmente à justiça federal.

De forma semelhante, o STJ também já afirmou que caberia à União, mesmo em execução movida na justiça federal, "adiantar as despesas com 0 transporte/condução/deslocamento dos oficiais de justiça necessárias ao cumprimento da carta precatória de penhora e avaliação de bens (processada na Justiça Estadual)". ${ }^{60}$ Notese que esse entendimento só fará sentido quando o deslocamento do oficial de justiça não for custeado, direta ou indiretamente, pela própria administração. Isso porque nada impede que o seu transporte para a prática de atos seja realizado em veículo do próprio Poder Judiciário. ${ }^{61}$

O mesmo raciocínio aplica-se para os honorários do perito, já mencionado no item 2.1, inteiramente aplicável à execução fiscal. ${ }^{62} \mathrm{O}$ STJ também possui o entendimento de que "a Fazenda não está isenta do pagamento das custas processuais devidas às serventias não oficializadas", em que os serventuários não são remunerados pelos cofres públicos. ${ }^{63}$

\footnotetext{
59 “A Fazenda Pública nas execuções fiscais, não está sujeita a prévio depósito para custear despesas de oficial de justiça".

${ }^{60}$ STJ, ${ }^{a}$ Seção, REsp 1.144.687/RS, Rel. Min. Luiz Fux, j. 12/05/2010, DJe 21/05/2010, tema repetitivo 396. ${ }^{61}$ SILVA NETO, Francisco Antônio de Barros e. A improbidade processual da Administração Pública e sua responsabilidade objetiva pelo dano processual... cit., p. 205.

62 Aponta destacar que, em livro escrito logo após a entrada em vigor da LEF, entendia-se que a dispensa de custas abrangeria também os valores a serem adiantados ao perito, ao mesmo tempo em que constatava as dificuldades que isso iria gerar para convencer peritos a atuar nesse caso: FLAKS, Milton. Comentários à lei de execução fiscal. Rio de Janeiro: Forense, 1981, p. 347.

63 STJ, $1^{\mathrm{a}}$ T., AgInt no AREsp 388.027/SC, Rel. Min. Napoleão Nunes Maia Filho, j. 08/02/2018, DJe 23/02/2018; STJ, AgRg no AREsp. 370.012/SC, Rel. Min. Benedito Gonçalves, DJe 17/03/2016; STJ, AgRg no REsp. 1.180.324/PR, Rel. Min. Luiz Fux, DJe 3.8.2010; EREsp. 889.558/PR, Rel. Min. Eliana Calmon, DJe 23.11.2009.
} 
Revista Eletrônica de Direito Processual - REDP.

Rio de Janeiro. Ano 16. Volume 23. Número 1. Janeiro a Abril de 2022

Periódico Quadrimestral da Pós-Graduação Stricto Sensu em Direito Processual da UERJ

Patrono: José Carlos Barbosa Moreira (in mem.). ISSN 1982-7636. pp. 1228-1254

www.redp.uerj.br

Em 2020, foi afetado ao rito dos repetitivos a discussão "acerca da obrigatoriedade, ou não, de a fazenda pública exequente, no âmbito das execuções fiscais, promover o adiantamento das custas relativas às despesas postais referentes ao ato citatório" (tema 1.054). A tendência parece ser a de entender que não há essa obrigatoriedade, pois há vários julgados anteriores, no qual prevalece a posição de que "o referido encargo se enquadra no conceito de custas processuais, encontrando-se abrangido pela regra do art. 39 da LEF". 64

A resposta adequada para a questão posta no STJ não deve ser simplesmente a de que tais dispêndios financeiros devem estar sujeitos ou não ao art. 39 da LEF. Isso porque a resposta dependerá da lei de custas de cada ente. Como apontado no item 2, a legislação de custas pode incluir, em seu pagamento, as despesas com os correios, ou mesmo optar pela sua separação, que são inegavelmente despesas direcionadas a terceiros, não relacionados com a atividade jurisdicional. É inegável que a taxa exigida pelo serviço judiciário de realizar a citação é diferente dos valores dispendidos para o envio da carta de citação pelo correio.

Ocorre que a lei de custas não é produzida pensando apenas no regime de despesas do Poder Público. Assim, poderá a legislação inserir, nas custas exigidas para a citação, o valor das despesas para envio da correspondência ou não, sendo esse o elemento crucial para identificar qual o regime aplicável na execução fiscal. Caso a legislação insira nas custas esses valores, o Poder Público deve ser isento, caso contrário, em havendo a separação, impõe-se o adiantamento de tais valores.

\section{CONSIDERAÇÕES FINAIS}

As despesas processuais podem ser divididas em custas, emolumentos e despesas em sentido estrito; as duas primeiras são taxas, as últimas não possuem natureza tributária. Do ponto de vista da Fazenda Pública, não há, como regra geral, uma isenção, mas tão

${ }^{64}$ STJ, $2^{\text {a }}$ T., REsp 1.776.942/SP, Rel. Min. Herman Benjamin, j. 11/06/2019, DJe 18/06/2019. No mesmo sentido: ${ }^{64}$ STJ, $2^{\mathrm{a}}$ T., REsp 1.848.285/SP, Rel. Min. Herman Benjamin, j. 04/02/2020, DJe 27/02/2020; STJ, $2^{\mathrm{a}}$ T., REsp 1.342.857/MG, Rel. Min. Mauro Campbell Marques, DJe 28/09/2012; REsp 1.332.428/RS, Rel. Min. Herman Benjamin, DJe 03/09/2012. 
Revista Eletrônica de Direito Processual - REDP.

Rio de Janeiro. Ano 16. Volume 23. Número 1. Janeiro a Abril de 2022 Periódico Quadrimestral da Pós-Graduação Stricto Sensu em Direito Processual da UERJ

Patrono: José Carlos Barbosa Moreira (in mem.). ISSN 1982-7636. pp. 1228-1254 www.redp.uerj.br

apenas um diferimento do pagamento das despesas. Esse diferimento, no entanto, não deve atuar nos casos das despesas em sentido estrito, a exemplo das despesas com o perito.

Há um ponto que gera certa divergência jurisprudencial entre o STJ e o STF, relacionado ao preparo, havendo a necessidade de diferenciação entre a regra processual que exige o adiantamento das despesas para prática de atos, da regra tributária que institui ou não o tributo. Na verdade, a União pode alterar o regime processual das custas, por ter competência privativa para legislar sobre direito processual, mas não pode dispensar as custas, pois estaria praticando isenção heterônoma, vedada pela Constituição.

Em relação às hipóteses de isenção das custas pela Fazenda Pública, é possível identificar que há divergência doutrinária e jurisprudencial sobre a existência de confusão na eventual cobrança de custas quando o ente litiga na própria justiça. Além disso, são comuns as regras que preveem isenção das despesas processuais, seja na justiça federal, de forma geral, seja nas justiças estaduais, sendo raros os estados nos quais não há previsão de isenção. No entanto, mesmo com as regras de isenção tributária, a litigância do Poder Público não está imune à obrigatoriedade do adiantamento de despesas em sentido estrito, situação na qual ele atuará como qualquer particular.

Por fim, percebe-se que a Fazenda Pública, na ausência de regra que especifique o seu regime de despesas processuais, para além da prerrogativa do seu diferimento, atual em regime de igualdade com os particulares.

\section{REFERÊNCIAS:}

ASSIS, Araken de. Manual dos recursos. $9^{\text {a }}$ ed. São Paulo: RT, 2017. Processo civil brasileiro. São Paulo: RT, 2015, v. II, t. I.

BARBOSA MOREIRA, José Carlos. Comentários ao código de processo civil. 14 ed. Rio de Janeiro: Forense, 2008, v. V.

BENEDUZI, Renato. Comentários ao código de processo civil. São Paulo: RT, 2018, t, II, versão eletrônica.

CAMARGO, Luiz Henrique Volpe. Comentários ao art. 84. In: DIDIER JR., Fredie; WAMBIER, Teresa Arruda Alvim; TALAMINI, Eduardo; DANTAS, Bruno (coord.). Breves comentários ao novo código de processo civil. São Paulo: RT, 2015. 
Revista Eletrônica de Direito Processual - REDP.

Rio de Janeiro. Ano 16. Volume 23. Número 1. Janeiro a Abril de 2022

Periódico Quadrimestral da Pós-Graduação Stricto Sensu em Direito Processual da UERJ

Patrono: José Carlos Barbosa Moreira (in mem.). ISSN 1982-7636. pp. 1228-1254

www.redp.uerj.br

CUNHA, Leonardo Carneiro da. A Fazenda Pública em juízo. 17 ed. Rio de Janeiro: Forense, 2020.

CUNHA, Leonardo Carneiro da; DIDIER JR., Fredie. Curso de direito processual civil. 15 ed. Salvador: Juspodivm, 2018, v. 3.

DINAMARCO, Candido Rangel. Instituições de direito processual civil. $7^{\mathrm{a}}$ ed. São Paulo: Malheiros, 2017, t. II.

FLAKS, Milton. Comentários à lei de execução fiscal. Rio de Janeiro: Forense, 1981.

KOZIKOSKI, Sandro Marcelo. Sistema recursal CPC/2015. Salvador: Juspodivm, 2015.

MARQUES, José Frederico. A reforma do poder judiciário. São Paulo: Saraiva, 1979.

MARQUES, Leonardo Albuquerque; FREIRE, Alexandre. Comentários ao art. 91. In:

CUNHA, Leonardo Carneiro da; STRECK, Lenio Luiz; NUNES, Dierle (orgs.).

FREIRE, Alexandre (coord. Exec.). $2^{\mathrm{a}}$ ed. São Paulo: Saraiva, 2017.

MOLITERNO, Marcella Parpinelli. Garantias e privilégios da Fazenda Públic na execução

fiscal. In: FERREIRA FILHO, Marcílio da Silva; LIMA, Rodrigo Medeiros de (coords.). Execução fiscal: teoria, prática e atuação fazendária. $2^{\mathrm{a}}$ ed. Belo Horizonte: Fórum 2017.

NERY JR., Nelson. Teoria geral dos recursos. $6^{\mathrm{a}}$ ed. São Paulo: RT, 2004.

ROCHA, Jorge Bheron; OLIVEIRA, Alfredo Emanuel Farias de; NEVES, Otávio Vilela Miranda. A defensoria pública e os honorários de sucumbência: breves anotações sobre a súmula 421 do Superior Tribunal de Justiça. In: ROCHA, Jorge Bheron; OLIVEIRA, Alfredo Emanuel Farias de; PITTARI, Mariella; MAIA, Maurilio Casas. Teoria geral da defensoria pública. Belo Horizonte: D’Plácido, 2020.

SILVA NETO, Francisco Antônio de Barros e. A improbidade processual da Administração Pública e sua responsabilidade objetiva pelo dano processual. Rio de Janeiro: Lumen Juris, 2010.

THEODORO JÚNIOR, Humberto. Lei de execução fiscal. 13a ed. São Paulo: Saraiva, 2016, versão digital. 